\title{
SOME WATER MITES (ACARI, HYDRACHNIDIA) FROM CALDERA DE TABURIENTE NATIONAL PARK (LA PALMA, CANARY ISLANDS)
}

\author{
A. G. Valdecasas *
}

\begin{abstract}
Protzia cf. lata, Lebertia fimbriata Thor, 1899; Limnesia martianezi Lundblad, 1962; Atractides gomerae Lundblad, 1962 are mentioned for the first time for the island of La Palma: Feltria menzeli Walter, 1922 and Aturus atlantica Lundblad, 1942 for the first time in the Canary islands. It is the first record of the genus Feltria Koenike, 1892 in Macaronesia.
\end{abstract}

Key words: Hydrachnellae, Macaronesia, new findings.

\section{RESUMEN}

Nuevos ácaros acuáticos (Acari, Hydrachnidia) del Parque Nacional de la Caldera de Taburiente (La Palma, islas Canarias)

Protzia cf. lata, Lebertia fimbriata Thor, 1899; Limnesia martianezi Lundblad, 1962; Atractides gomerae Lundblad, 1962 han sido encontradas por primera vez en la isla de La Palma: Feltria menzeli Walter, 1922 and Aturus atlantica Lundblad, 1942 son nueva cita para las islas Canarias y es la primera vez que se registra el género Feltria Koenike, 1892 en Macaronesia.

Palabras clave: Hidracnelas, Macaronesia, nuevas citas.

\section{Introduction}

The fauna of water mites (Acari, Hydrachnidia) of the Canary islands is not very well known. Four previous contributions (Lundblad, 1962, 1972; Viets, 1968; Gerecke, 1999) have risen the number of species found to 16, distributed between Gran Canaria, Tenerife, La Palma and Gomera. No doubts many more species could be found if continued and systematic sampling is done.

In this paper we report several additional records deriving from a three days sampling trip to La Palma, as well as continuous sampling done along a year, during the study on the arthropod fauna of the Caldera de Taburiente National Park on that island (see Alonso Zarazaga et al., in prep.)

\section{Methods and habitats sampled}

Sampling was done between 22 and 24 March 2001. Twenty four samples were taken in different habitats, including: springs, wet moss in walls, torrent water, Karaman-Chappuis (a hole done near a stream successively filled with interstitial water), streams and small waterfalls. Samples were

* Museo Nacional Ciencias Naturales. C/ José Gutiérrez Abascal, 2. 28006-Madrid. Spain 
washed through a $0.250 \mathrm{~mm}$ sieve and fixed in Angelier's fluid (Valdecasas and Baltanás, 1989). In the laboratory, the samples were washed again, the mites sorted and kept in Koenike's fluid before dissection.

Some additional mites conserved in alcohol, obtained during a year sampling study of the Caldera de Taburiente National Park (Alonso Zarazaga et al., in prep.) were also studied.

Only water mites in the sense of Cook (1974) are studied here. Some of the habitats had any mite.

LOCALITIES: Only the habitats with water mites are given (Fig. 1). The mites from the first three were conservated with Angelier's fluid, all the other with alcohol. For a more detailed description of the localities, see Alonso Zarazaga et al. (in prep.).

Fuente Prieta: UTM 28RBS2181-4: Protzia cf. lata, Feltria menzeli, Lebertia fimbriata, Torrenticola gomerae, Atractides gomerae, Sperchon hispidus.

Hoyo Verde (AD45, HV3): UTM 28RBS1882-3: Eylas planipons novata, Aturus atlanticus, Protzia cf. lata, Sperchon hispidus, Atractides gomerae, Lebertia fimbriata.

Piedra Majorera (AD23, AD23A, AD67, ADZ3B): UTM 28RBS2281-2: Eylais planipons novata, Protzia cf lata, Feltria menzeli, Lebertia fimbriata, Aturus atlanticus, Torrenticola gomerae.

(AD5E, D6E, AD57, AD75): UTM 28RBS1977-1. Protzia of lata, Lebertia fimbriata, Atractides gomerae.

(AD28): UTM 28RBS2082-4. Torrenticola gomerae, Atractides gomerae.

(AD41, AD42, ADZA2, AD93): UTM 28RBS1980-1. Eylais planipons novata, Protzia cf lata, Sperchon hispidus, Atractides gomerae.

(AD63): UTM 28RBS2180-3. Limnesia martianezi.

(AD70, AD71, AD74, 13H): UTM 28RBS1879-4. Eylais planipons novata, Sperchon hispidus.

(AD77): UTM 28RBS2078-4. Torrenticola gomerae.

(6E): UTM 28RBS1878-3: Sperchon hispidus.

(AD79): UTM 28RBS2176-4 Torrenticola gomerae, Atractides gomerae.

(3108A): UTM 28RBS1780-2. Eylais planipons novata.

\section{Results}

Superfamily Eylaoidea

Family Eylaidae Leach, 1815

\section{Eylais planipons novata Viets, 1942}

In 1962, Lundblad described the species Eylais canariensis from several localities in the Canary islands. After that, Viets (1968) found several specimens of Eylais planipons novata Viets, 1942 and taking in account the variability of this species, he decided that canariensis is a synonym of the later. Eylais species are very variable, and quite probably only molecular evidence could clear the taxonomic value of the present subspecific morphological variation. Previously found in Tenerife, Gran Canaria, La Palma and Gomera.

NEW RECORDS: 3108A; HV-3; ADZA2; AD93; AD74; AD23A; AD42; AD23.

\section{Superfamily Hydryphantoidea}

Family Hydryphantidae Thor, 1900

\section{Trichothyas (Lundbladia) petrophila rutae} (Lundblad, 1941)

Previously described with species rank but now considered only a subspecies (see Gerecke, 1996a y b for a recent review and past bibliography). Only one female specimen was found. The dorsal, ventral and palp morphology agree with the description given by Lundblad (1941). Previously found in Tenerife, La Palma and Gomera.

NEW RECORD: AD5E.

$$
\begin{gathered}
\text { Superfamily Hydryphantoidea } \\
\text { Family Hydryphantidae Thor, } 1900
\end{gathered}
$$

\section{Protzia cf. lata Walter, 1906}

This is a variable species. We have found several males and females that fit within the range of variation given in the re-description done by Gerecke (1996a, 1996b).

Main characteristics of the lata group are: coxa1 with an apical set of some 10 seta; medial border of coxa-3 protruding; around 20 genital acetabula; small genital sclerite as in the figure (Fig. 2B); claw clawlets as illustrated (Fig. 2A). Gerecke (1999) described Protzia faber from Gomera. The variability of the genital area of the set of specimens available to me doesn't fit well with his description of faber and there are other differences in the palp as well, so it is possible that we are dealing with a new species. I prefer to postpone a decision until I have studied more material

NEW RECORDS: ADZ3B; ADZA2; AD57; AD45; AD67; AD75; Fuente Prieta; Hoyo Verde.

COMment: This is the first time that the genus Protzia is found in La Palma. 


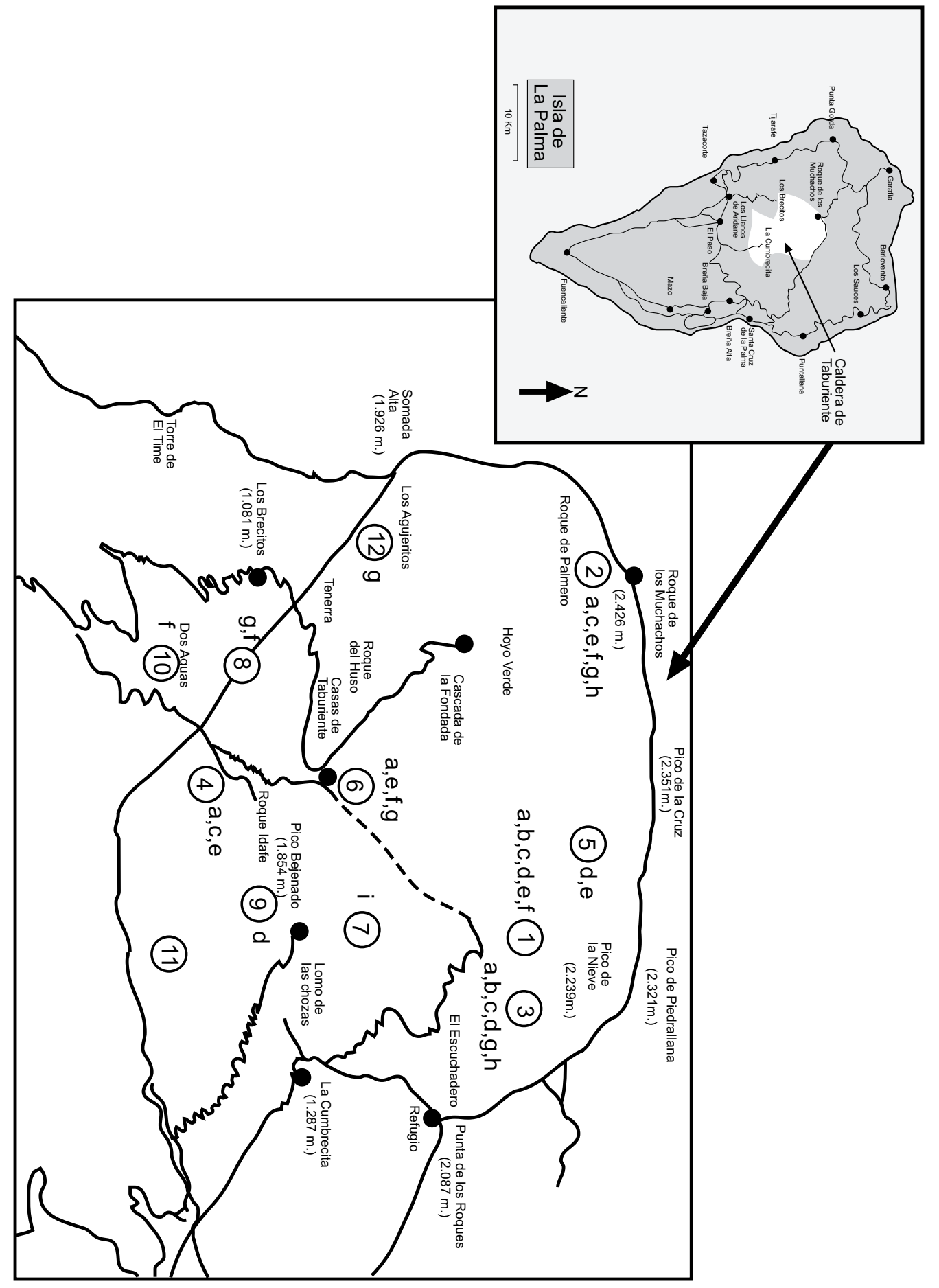

Fig. 1.- Caldera de Taburiente National Park, La Palma, Canary islands: Protzia cf. lata (a), Feltria menzeli (b), Lebertia fimbriata (c), Torrenticola gomerae (d), Atractides gomerae (e), Sperchon hispidus (f), Eylais planipons novata (g), Aturus atlanticus (h), Limnesia martianezi (i).

Fig. 1.- Parque Nacional de la Caldera de Taburiente, La Palma, islas Canarias: Protzia cf. lata (a), Feltria menzeli (b), Lebertia fimbriata (c), Torrenticola gomerae (d), Atractides gomerae (e), Sperchon hispidus (f), Eylais planipons novata (g), Aturus atlanticus (h), Limnesia martianezi (i). 

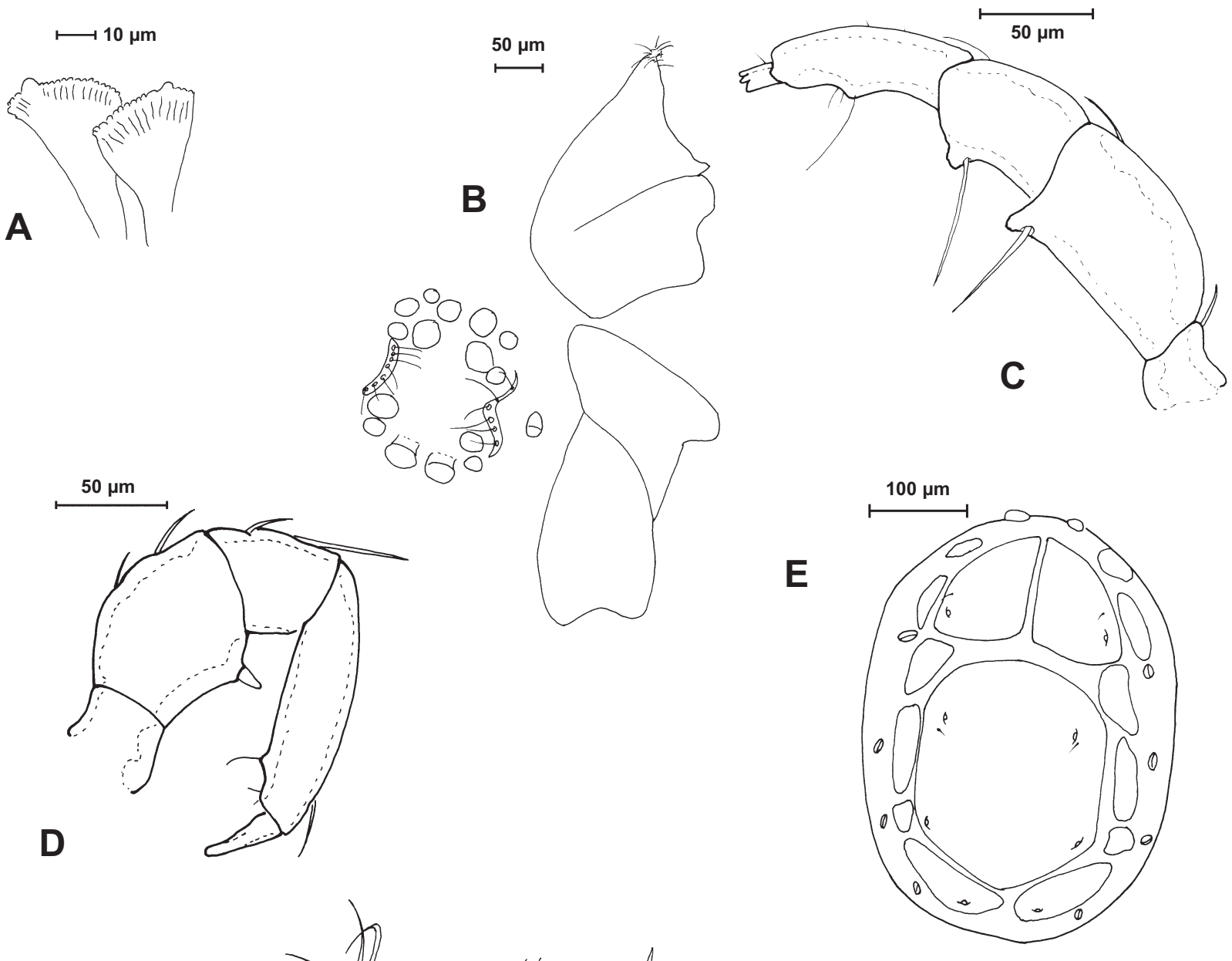

E
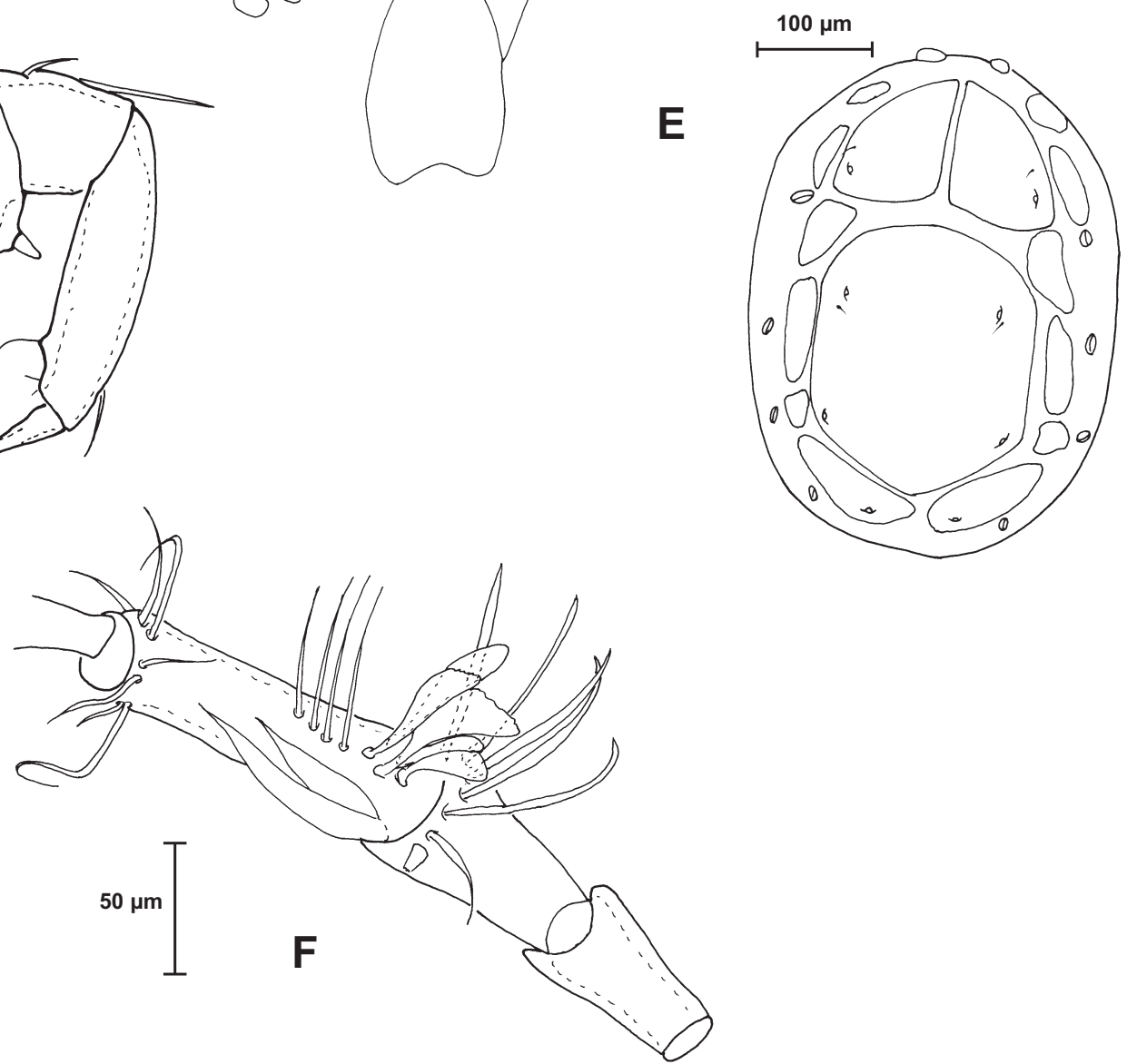

Fig. 2.- Protzia cf lata (A) clawlet I-leg-6; (B) left coxa and genital area male; Torrenticola gomerae,(C) palp; Limnesia martianezi, (D) palp; Feltria menzeli (E) dorsal surface female; Aturus atlanticus (F) I-leg 4-5.

Fig. 2.- Protzia cf lata (A) uña I-pata-6; (B) coxa izquierda y área genital del macho; Torrenticola gomerae,(C) palpo; Limnesia martianezi, (D) palpo; Feltria menzeli (E) superficie dorsal de la hembra; Aturus atlanticus (F) I-pata-4-5. 
Superfamily Lebertioidea

Family Sperchontidae Thor, 1900

Sperchon hispidus Koenike, 1895

Lundblad (1962) described a new forma of the species Sperchon hispidus Koenike, 1895 S. $h$. canariensis, but Viets (1968) considers that this forma does not merit taxonomic distinction.

Previously found in La Palma and Gomera.

NEW RECORDS: 13H; 6E; ADZA2; AD71; AD70; AD45; AD41; AD42; Fuente Prieta; Hoyo Verde.

\section{Superfamily Lebertioidea}

Family Lebertiidae Thor, 1900

Lebertia fimbriata Thor, 1899

Similar to the specimen described by Lundblad from Gomera (Lundblad, 1972).

Previously found in Gomera.

NEW RECORDS: AD75; Cascada de la Piedra Majorera; Fuente Prieta; Hoyo Verde.

\section{Superfamily Lebertioidea}

Family Torrenticolidae Piersig, 1902

Torrenticola (Torrenticola) gomerae Lundblad, 1972

Two Torrenticola species have been described for the Canary islands: T. palmensis Lundblad, 1962 and T. gomerae Lundblad, 1972. Both are related with Torrenticola elliptiformis (Lundblad, 1941) from Madeira. The ventral surface of palp segments II and III of T. gomerae, with their apical end stretched as in the figure (Fig. 2C), are diagnostic.

Previously found in La Palma.

NeW RECORDS: AD28; AD77; AD79; Cascada de la Piedra Majorera; Fuente Prieta.

\section{Superfamily Hygrobatoidea \\ Family Limnesiidae Thor, 1900}

\section{Limnesia martianezi Lundblad, 1962}

Originally described from Tenerife from a female specimen. The specimen found is a male and the second specimen found of this species. It is very close to L. atlantica Lundblad, 1941 described from Madeira. I give below some body measurements to complete the description, but as the specimen was preserved in alcohol, they should be taken critically. Dorsal length: $720 \mu \mathrm{m}$; body width: 550 $\mu \mathrm{m}$; genital area $190 \mu \mathrm{m}$ in length, $140 \mu \mathrm{m}$ in width; dorsal length palp segments: P-I: $25 \mu \mathrm{m}$; PII: $85 \mu \mathrm{m}$; P-III: $70 \mu \mathrm{m}$; P-IV: $120 \mu \mathrm{m}$; P-V: 35; capitulum: $155 \mu \mathrm{m}$ in length; chelicerae: $288 \mu \mathrm{m}$ in length (Fig. 2D).

R. Gerecke (in litteris, 25/Nov./2002) has pointed out the possibility that L. martianezi is a synonym of $L$. arevaloi, Viets 1918: "I remember that Henk Van der Hammen had made a confront between the types of this species and L.arevaloi, and he was convinced that they are synonym".

After comparing previous descriptions of $L$. arevaloi, including the original Viets paper, and due to the fact that the single specimen is poorly preserved, I can not confirm the synonym and prefer to keep the present status until further material is available. NEW RECORD: AD63.

$$
\begin{gathered}
\text { Superfamily Hygrobatoidea } \\
\text { Family Hygrobatidae Koch, } 1842
\end{gathered}
$$

Atractides gomerae Lundblad 1962

Structure of the palp and last segments of first leg as illustrated by Lundblad, 1962.

Previously found in Gomera.

NEW RECORDS: AD45; AD28; AD41; AD6E; AD79; Fuente Prieta.

\section{Superfamily Hygrobatoidea}

Family Feltriidae Viets, 1926

\section{Feltria menzeli Walter, 1922}

Only female specimens have been found that agree with Walter's (1922) original description. Fig. 2E illustrates the dorsal view. The dorsoglandularia C (sensu Cook, 1961) show different degree of fusion with the single dorsal plate $\mathrm{D}$ in the different specimens sampled. This taxon was previously recorded from Switzerland, Algeria and Corsica.

New ReCords: Cascada de la Piedra Majorera; Fuente Prieta.

COMmEnT: This is the first time that the genus Feltria Koenike, 1892 is found in Macaronesia.

\section{Superfamily Hygrobatoidea \\ Family Aturidae Thor, 1900}

\section{Aturus atlantica Lundblad, 1942}

The specimen agrees with Lundblad's original description, especially in the setation of segments 4-5 of the fourth leg (Fig. 2F) and the distal seg- 
ments of the third leg, besides dorsal and ventral body morphology.

NEW RECORDS: Cascada de la Piedra Majorera; Hoyo Verde.

Comment: The genus Aturus Kramer, 1875 is new for the Canary islands.

\section{ACKNOWLEDGEMENTS}

This work was done with the financial help of the project "Inventario y estudio de la fauna invertebrada del Parque Nacional de la Caldera de Taburiente" (Convenio Parques Nacionales-CSIC) directed by Miguel Ángel Alonso Zarazaga. Teresa Domingo Quero, Antonio Sánchez Ruiz, Eduardo Pérez Cáceres and Ángel Palomares helped during the sampling trip. Reinhard Gerecke revised a previous draft of the manuscript. This work could not have been finished without the encourage and help of Ana Camacho.

\section{References}

Cook, D. R., 1961. Water mites of the genus Feltria in central and western United States (Acarina: Feltriidae). Annals of the Entomological Society of America, 53: 35-60.

Cook, D. R., 1974. Water mite genera and subgenera. Memoirs of the American Entomological Institute, 21: 1-860.

GERECKE, R., 1996a. Untersuchungen über Wassermilben der Familie Hydryphantidae (Acari, Actinedida) in der Westpalaearktis, I. Beitrag zur Kenntnis der Gattung Protzia Piersig, 1896 (Acari, Actinedida, Hydryphantidae). Archiv für Hydrobiologie Supplement, 77: 271-336.

GERECKE, R., 1996b. Untersuchungen über Wassermilben der Familie Hydryphantidae (Acari, Actinedida) in der Westpalaearktis, II. Die Wassermilben der Familie Hydryphantidae Piersig, 1896 in den Mittelmeerländern. Archiv für Hydrobiologie Supplement, 77: 337-513.
GereCKE, R., 1999. Further studies on hydryphantoid water mites in the $\mathrm{W}$ Palaearctic region (Acari, Actinedida). Archiv für Hydrobiologie Supplement, Monographic Studies, 121(2): 119-158.

LunDBlad, O., 1941 Neue Wassermilben aus Madeira. Entomologisk Tidskrif, 62: 93-96.

LundBlad, O., 1962. Wassermilben von den Kanarischen Inseln. Arkiv för Zoologi, 15: 285-300.

LundBlaD, O., 1972. Einige Wassermilben aus Mallorca, Gomera und Kamerun. Entomologisk Tidskrif, 93: 113-122.

Valdecasas, A. G. \& Baltanás, A., 1989. A note on the use of Angelier's fluid for freshwater invertebrates. Archiv für Hydrobiology, 115: 313-316.

VIETS, K. O., 1968. Ueber einige Wassermilben (Hydrachnellae, Acari)von den Kanarischen Inseln. Gewässer und Abwässer, 47: 74-77.

VIETS, K. O., 1970. Unser Zuwachs an Kenntnissen über die aus Afrika bekannten Wassermilben (Hydrachnellae, Acari). Hydrobiologia, 35: 65-126.

WALTER, C., 1922. Hydracarinen aus den Alpen. Revue Suisse de Zoologie, 29: 227-411.

Recibido, el 14-XI-2002

Aceptado, el 17-XII-2002

Publicado, el 31-XII-2002 